Published in final edited form as:

J Neurovirol. 2003 June ; 9(3): 300-314.

\title{
The chemokine receptor CXCR4 regulates cell-cycle proteins in neurons
}

\author{
Muhammad Zafrullah Khan ${ }^{1}$, Renato Brandimarti ${ }^{1,2}$, Brian Joseph Musser ${ }^{1}$, Danielle Marie \\ Resue $^{1}$, Alessandro Fatatis ${ }^{1}$, and Olimpia Meucci ${ }^{1}$ \\ 1 Department of Pharmacology and Physiology, Drexel University College of Medicine, Philadelphia, \\ Pennsylvania, USA \\ 2Department of Experimental Pathology, University of Bologna, Italy
}

\section{Abstract}

\begin{abstract}
Neurons express a variety of chemokine receptors that regulate neuronal signaling and survival, including CXCR4 and CCR5, the two major human immunodeficiency virus (HIV) coreceptors. However, the role of chemokine receptors in HIV neuropathology and neuroinflammatory disorders is still unclear. This study aims to determine whether chemokine receptors regulate the activity of cell-cycle proteins in neurons and evaluate the possibility that alterations of these proteins are involved in HIV neuropathogenesis. The authors studied the effect of the chemokine stromal cellderived factor (SDF)-1 $\alpha$, the natural CXCR4 ligand, and an X4-using variant of gp120 on the activity of cell-cycle proteins involved in neuronal apoptosis and differentiation, such as Rb and E2F-1. Changes in expression, localization, and phosphorylation/activation of $\mathrm{Rb}$ and $\mathrm{E} 2 \mathrm{~F}-1$ induced by SDF-1 $\alpha(20 \mathrm{nM})$ gp $120_{\text {IIIB }}(200 \mathrm{pM})$ were analyzed in primary cultures of rat neurons and in a human cell line expressing recombinant CXCR4. The data indicate that changes in the nuclear and cytosolic levels of $\mathrm{Rb}$ - which result in the functional loss of this protein - are associated with apoptosis in hippocampal or cerebellar granule neurons and in cell lines. SDF- $1 \alpha$, which is able to rescue these neurons from apoptosis, induces a time-dependent increase of total $\mathrm{Rb}$ expression while decreasing the nuclear content of phosphorylated (Ser780/Ser795) Rb and the transcriptional activity of E2F-1. The HIV envelope protein gp120 $0_{\text {IIIB }}$ exerts opposite effects at the nuclear level. These data indicate that CXCR4 affects cell-cycle proteins in neurons and raise the possibility that chemokines may contribute to neuronal survival by repressing the activity of E2F-dependent apoptotic genes and maintaining neurons in a highly differentiated and quiescent state. This state may be altered during neuroinflammatory conditions and/or by HIV-derived proteins.
\end{abstract}

\section{Keywords}

apoptosis; cell-cycle proteins; gp120; HIV neuropathology; neuronal differentiation; SDF-1 $\alpha$

\section{Introduction}

The chemokine stromal cell-derived factor (SDF)- 1 and its receptor CXCR4 are constitutively expressed in the developing and adult brain by both neuronal and non-neuronal cells and are implicated in several physiological processes in the central nervous system (CNS), such as neurogenesis and connectivity (Ma et al, 1998; Zou et al, 1998; Asensio and Campbell,

\footnotetext{
Address correspondence to Olimpia Meucci, MD, PhD, Drexel University College of Medicine, Department of Pharmacology and Physiology, 245 N. 15th Street, NCB\#8804, Philadelphia, PA 19102, USA. E-mail: E-mail: Olimpia.Meucci@drexel.edu.

Muhammad Zafrullah Khan and Renato Brandimarti contributed equally to the work.
} 
1999; Bajetto et al, 1999; Hesselgesser and Horuk, 1999; Lu et al, 2001, 2002; Zhu et al, 2002). The developmental and injury-induced regulation of SDF-1/CXCR4 expression in discrete CNS areas indicates that this chemokine/receptor pair may play different roles throughout life (Tham et al, 2001; Van Der Meer et al, 2001; Stumm et al, 2002). SDF-1 $\mu$ appears to regulate survival of neuronal progenitors and mature neurons (Hesselgesser $e t a l$, 1998; Meucci et al, 1998; Kaul and Lipton, 1999; Klein et al, 2001). However, although both neuroprotective and neurotoxic actions of SDF- $1 \mu$ have been reported, the role of CXCR4 in the survival of differentiated neurons under physiological conditions is still unclear. Evidence indicates that its inappropriate activation may be involved in neuroinflammatory and neurodegenerative diseases, including human immunodeficiency virus (HIV)-associated dementia (HAD) (Ransohoff et al, 1997; Asensio and Campbell, 1999; Miller and Meucci, 1999; Asensio and Campbell, 2001). In addition to its role as HIV coreceptor (Feng et al, 1996), CXCR4 may participate in HIV-induced neuropathogenesis through the activation of specific apoptotic pathways in neurons and glia (Hesselgesser et al, 1998; Kaul and Lipton, 1999; Zheng and Lee, 1999; Garden et al, 2002). These pathways can be activated by the direct interaction of CXCR4 with the HIV-1 envelope protein gp120, as indicated by in vitro and in vivo studies (Kaul et al, 2001).

Alterations of cell-cycle proteins, such as inappropriate activation of the $\mathrm{CDK} / \mathrm{Rb} / \mathrm{E} 2 \mathrm{~F}-1$ pathway-which may result in an abortive attempt to reenter the cell cycle-have often been implicated in neuronal apoptosis (Giovanni et al, 2000; O'Hare et al, 2000; Osuga et al, 2000; Park et al, 2000). It is generally believed that the retinoblastoma gene product, $\mathrm{Rb}$, displays neuroprotective functions and that its loss is associated with apoptosis (Macleod, 1999; Harbour and Dean, 2000a; Zheng and Lee, 2001). Although the molecular mechanisms involved are still not clearly defined, many data show that neuronal apoptosis derives from the inability of $\mathrm{Rb}$ to control the action of proteins directly involved in the regulation of cell-cycle progression and cell death (Sears and Nevins, 2002). For example, one of the major Rb targets is the transcription factor E2F-1, which activates expression of apoptotic genes (i.e., Apaf-1, $\mathrm{p} 53$, and $\mathrm{Bax}$ ) as well as genes required for entry into $\mathrm{S}$ phase, and down-regulates the activation of antiapoptotic signals (i.e., nuclear factor [NF]- $\mu \mathrm{B}$ ) (Phillips et al, 1999; Harbour and Dean, 2000b; Moroni et al, 2001). E2F-1 is regulated by direct interaction with Rb (Dyson, 1998). Phosphorylation of Rb by cyclin-dependent kinases (CDKs) (i.e., CDK4) abolishes this interaction, leading to loss of repression and promotion of E2F-1 transcriptional activity. Indeed, $\mathrm{Rb}$-null mice show neurological deficits and neuronal apoptosis, which may be reverted by E2F-1 mutation (Jacks et al, 1992). Ectopic expression of E2F-1 in proliferating cells as well as neurons induces apoptosis (Phillips et al, 1999; O'Hare et al, 2000).

Recently, changes in the expression and activity of cell-cycle proteins (Rb, E2F-1, and p53) have been reported in the brains of HIV-demented patients and monkey with simian immunodeficiency virus (SIV) encephalitis (Jordan-Sciutto et al, 2000, 2002), suggesting that alterations of the $\mathrm{CDK} / \mathrm{Rb} / \mathrm{E} 2 \mathrm{~F}-1$ pathway may be implicated in HIV neuropathogenesis. To start investigating this hypothesis, we have asked the question of whether CXCR4 can regulate $\mathrm{Rb}$ and E2F-1 activities in cultures of differentiated rat neurons. We have focused on two specific brain areas in which CXCR4 is physiologically relevant, i.e., the cerebellum and the hippocampus (Zou et al, 1998; Klein et al, 2001; Lu et al, 2002). A human cell line overexpressing CXCR4 (HOS cells) has been used to monitor the behavior of the isolated receptor in a different cellular model.

The data presented here indicate that SDF- $1 \mu$ modulates the expression and activation state of both $\mathrm{Rb}$ and E2F-1, and raise the possibility that the neuroprotective effect of this chemokine may be related to its ability to increase $\mathrm{Rb}$ levels, thus inhibiting transcription of apoptotic genes regulated by E2F-1. On the contrary, the apoptotic action of HIV envelope proteins- 
and possibly of SDF-1 $\mu$ in pathological situations - may be related to an opposite effect on this pathway.

\section{Results \\ SDF-1 $\mu$ prevents $\mathrm{Rb}$ loss and phosphorylation in cerebellar granule neurons undergoing apoptosis}

One of the best-characterized models of neuronal apoptosis in which $\mathrm{Rb}$ is implicated is the death of cerebellar granule neurons deprived of depolarizing concentrations of extracellular potassium, i.e., $25 \mathrm{mM} \mathrm{KCl} \mathrm{(K25)} \mathrm{(D'Mello} \mathrm{et} \mathrm{al,} \mathrm{1993;} \mathrm{Galli} \mathrm{et} \mathrm{al,} \mathrm{1995).} \mathrm{When} \mathrm{shifted} \mathrm{to} \mathrm{a}$ serum-free medium with $5 \mathrm{mM} \mathrm{KCl} \mathrm{(K5),} \mathrm{granule} \mathrm{neurons} \mathrm{undergo} \mathrm{apoptosis,} \mathrm{a} \mathrm{process} \mathrm{that}$ is preceded by several changes of cell-cycle regulators, including increased CDK4 activity, phosphorylation, and subsequent loss of the Rb protein, and up-regulation of E2F-1. Evidence indicates that these alterations are responsible for apoptosis of granule neurons (Boutillier $e t$ al, 1999; Padmanabhan et al, 1999; O'Hare et al, 2000; Trinh et al, 2001). Thus, we first studied whether SDF- $1 \mu$ could affect the changes in Rb and E2F-1 induced by $\mathrm{K} 5$ in granule neurons. For these experiments, neurons were cultured in K25 medium with serum for the first 6 to 7 days in vitro and then shifted to a $\mathrm{K} 5$ serum-free medium according to the experimental design. Control neurons were maintained in K25 and only deprived of serum as previously described (Galli et al, 1995). Untouched neurons (i.e., kept in original culture medium with serum and $\mathrm{K} 25$ ) were usually used as an internal control of survival.

As expected, total $\mathrm{Rb}$ levels decreased when neurons were deprived of extracellular potassium, an effect observed after a relatively short incubation in K5 (Figure 1). The addition of $\mathrm{SDF}-1 \mu(20 \mathrm{nM})$ to the $\mathrm{K} 5$ medium prevented $\mathrm{Rb}$ reduction within the first $6 \mathrm{~h}$ (Figure 1). Importantly, this time frame corresponds to the "point of no return" (i.e., commitment to death) for the induction of K5-induced apoptosis (Galli et al, 1995). A maximal effect of SDF- $1 \mu$ was observed in the very first hour (compared to K25, levels of Rb in K5 + SDF and K5 alone were around $80 \%$ and $45 \%$, respectively). Similar results were observed with higher concentrations of SDF- $1 \mu$ (50 and $100 \mathrm{nM}$, not shown). A modest increase of Rb levels (20\% to 30\%) was also observed when neurons were exposed to SDF- $1 \mu(20 \mathrm{nM})$ in K25 medium, whereas $\mathrm{SDF}-1 \mu$ was unable to affect $\mathrm{Rb}$ when added to neurons that had been deprived of potassium $5 \mathrm{~h}$ earlier (data not shown). This does not seem to be due to a reduced expression of CXCR4 in neurons cultured in low potassium, as we found no significant differences in the expression of CXCR4 at the single-cell level between control neurons (K25) and neurons cultured in K5 for several hours (up to $24 \mathrm{~h}$; Figure 2). These data indicate that the chemokine interferes with the earliest steps of the death signal cascade triggered by K5.

The ability of Rb to inhibit E2F-1 depends on its phosphorylation state, which also affects $\mathrm{Rb}$ localization and degradation (Dyson, 1998). Although several different sites of phosphorylation have been identified on $\mathrm{Rb}$, four residues $\mathrm{C}$-terminal to the pocket domain (Ser975/807/811/780) are critical for its interaction with E2F proteins and are targets of CDK4/6 (Taya, 1997). Thus, to evaluate whether the effect of SDF- $1 \mu$ on Rb may affect E2F-1 function, we probed the neuronal extracts with antibodies against Rb phosphorylated at Ser795 or Ser780. According to previous reports on cerebellar granule neurons, $\mathrm{Rb}$ phosphorylation on these residues by CDK4 is one of the earliest events in the K5-induced apoptotic cascade (Boutillier et al, 1999; Padmanabhan et al, 1999). As in the case of total Rb levels, we found that SDF- $1 \mu$ treatment prevented the phosphorylation of $\mathrm{Rb}$ caused by potassium deprivation (Figure 3), which is generally associated to the subsequent degradation of the protein and activation of apoptotic genes by E2F-1. 


\section{SDF- $1 \mu$ regulates $R b$ expression and localization in HOS cells}

To investigate the mechanism(s) involved in the action of SDF- $1 \mu$ at the total Rb level, we tested the effect of SDF-1 $\mu$ on a human cell line (HOS) that stably overexpresses CXCR4. The goal of these experiments was to gather information about potential changes in the cellular localization of $\mathrm{Rb}$ induced by SDF- $1 \mu$. Despite its major role as a nuclear protein, $\mathrm{Rb}$ is also expressed in the cytosol and it seems to translocate to the nucleus in association with other cellular factors (such as E2F-1) (Zacksenhaus et al, 1996, 1999). The subcellular localization of these proteins may, in fact, contribute to their regulation.

In case of HOS cells, cytosolic levels of Rb are greatly reduced when cells are incubated for 2 to $4 \mathrm{~h}$ in a saline solution (Figure $4 \mathbf{A}$ ), even though its nuclear level remains quite stable during that period, indicating that the lack of trophic factors is responsible for $\mathrm{Rb}$ degradation and loss. When we examined the effect of serum starvation on $\mathrm{Rb}$ expression over a longer period of time (from 6 to $48 \mathrm{~h}$ ), we also noticed that $\mathrm{Rb}$ accumulates in the nucleus in conjunction to its cytosolic decrement (Figure 4B). This effect could be related to the suppressive role of $\mathrm{Rb}$ in cell-cycle progression. Interestingly, both the decrease in cytosolic $\mathrm{Rb}$ and its accumulation into the nucleus were inhibited by SDF- $1 \mu$ (Figure $4 \mathbf{B}$ ) for the first $24 \mathrm{~h}$. After $48 \mathrm{~h}$ of starvation, the differences between SDF-treated and untreated cells are less dramatic (and even disappear at the nuclear level), possibly due to chemokine degradation and/ or to prolonged serum starvation. Overall, these experiments indicate that the chemokine may affect $\mathrm{Rb}$ synthesis and subcellular localization in these cells. Indeed, total $\mathrm{Rb}$ content increased in cells maintained in regular culture medium and treated with SDF- $1 \mu$ for 15 to $180 \mathrm{~min}$, as demonstrated by immunocytochemistry and Western blot analysis (Figure $5 \mathbf{A}, \mathbf{B}$ ). To determine whether this effect was related to new protein synthesis, HOS cells were pretreated for 4 to $5 \mathrm{~h}$ with cycloeximide (CHX, $1 \mu \mathrm{M}$ ) before being exposed to SDF- $1 \mu$ plus $\mathrm{CHX}(1 \mathrm{~h})$. As shown in Figure 5B, SDF- $1 \mu$ did not affect Rb level in CHX-treated cells. Thus, it is likely that in this experimental condition, the chemokine stimulates Rb expression. Finally, SDF- $1 \mu$ is also able to regulate the phosphorylation state of Rb in HOS cells, as indicated by Western blot analysis and in vitro kinase assays (Figure 5C). A reduction in the phosphorylated (Ser780) band of Rb was found in cells treated with SDF-1 $\mu$ and lower levels of phosphorylation were observed in in vitro kinase assays performed with protein extracts from SDF-treated cells. For these experiments, a gluthathione $S$-transferase (GST)-Rb fusion protein containing the $\mathrm{C}$-terminus region of $\mathrm{Rb}$ was used as a substrate for phosphorylation.

Taken together, these data suggest that SDF- $1 \mu$ may be involved in the regulation and trafficking of $\mathrm{Rb}$ being able to affect its synthesis and possibly degradation, nuclear translocation, as well as phosphorylation.

\section{Effects of SDF-1 $\mu$ on E2F-1}

Overexpression of E2F-1 can induce apoptosis of cerebellar granule neurons as well as other cells and increase in the level and activity of this transcription factor have been implicated in K5-induced apoptosis (O'Hare et al, 2000). In line with these data, we found that the DNAbinding activity of E2F-1 was higher than normal in preapoptotic neurons (Figure 6A).This effect was inhibited by SDF- $1 \mu$, suggesting that the chemokine may interfere with the apoptotic action of E2F-1. In support of this hypothesis, we found that in HOS cells, SDF- $1 \mu$ not only reduced E2F-1-binding activity (Figure 6A), but also led to accumulation of E2F-1 in the cytosol (Figure $6 \mathbf{B}$ ). Thus, the chemokine may reduce E2F-1 proapoptotic activity by "retaining" the protein into the cytosol-a mechanism that regulates the activity of other members of the E2F family - and favoring its degradation. This last possibility is also suggested by the reduced levels of total E2F-1 expression in cerebellar granule neurons treated with SDF-1 $\mu$ (Figure 6C). Further studies are in progress to confirm this hypothesis and determine the effect of SDF-1 $\mu$ on E2F-1 transcription activity. Interestingly, gp120 $0_{\text {IIIB }}$ did 
not reduce E2F-1 expression in these conditions (Figure 6C), in line with its inability to rescue neurons from K5-induced apoptosis (Figure 7A).

\section{The neuroprotective effect of SDF-1 $\mu$ correlates with the changes in cell-cycle proteins}

The effects of SDF- $1 \mu$ on Rb and E2F-1 expression suggest that SDF- $1 \mu$ may affect neuronal apoptosis induced by K5. For instance, SDF- $1 \mu$ may contribute to the survival of differentiated neurons by inhibiting cell-cycle progression and/or activation of apoptotic genes. Thus, we tested the ability of the chemokine to block K5-induced neuronal death. In agreement with our findings on Rb levels and phosphorylation, cell-survival experiments showed that SDF- $1 \mu$ was able to reduce neuronal cell death induced by potassium deprivation. The neuronal death induced by $\mathrm{K} 5$ after 20 to $22 \mathrm{~h}$ was reduced by almost $50 \%$ by SDF- $1 \mu$ (Figure 7A) —an effect abolished by the specific CXCR4 antagonist AMD3100 (Figure 7B). A similar degree of protection was observed by incubating neurons with the specific CDK4/6 inhibitor PD0183812 (Fry et al, 2001) (Figure 7A), suggesting that the neuroprotective action of SDF-1 $\mu$ might be related to the inhibition of $\mathrm{Rb}$ phosphorylation and its subsequent degradation. As expected, PD0183812 was also able to reduce phosphorylation and loss of $\mathrm{Rb}$ in these neurons (data not shown). Furthermore, preliminary experiments indicate that both SDF- $1 \mu$ and PD0183812 reduce the overexpression of cyclin D1 caused by potassium deprivation. In contrast, the HIV envelope protein gp120 IIIB did not inhibit K5-induced apoptosis (Figure 7A) and Rb phosphorylation (Figure 7B) - but rather increased Rb phosphorylation in normal conditions, i.e., K25 mM (Figure 7B , bottom), in agreement with previous evidence reporting gp120 neurotoxicity in these cultures (Savio and Levi, 1993). The viral protein seems also able to reduce nuclear expression of $\mathrm{Rb}$ in the HOS cells (data not shown).

To further evaluate the effect of gp120 on cell-cycle proteins, we performed similar experiments using primary cultures of hippocampal neurons. We have previously used this in vitro model of neuronal cultures to study the intracellular mechanisms implicated in gp120 neurotoxicity as well as the effect of chemokines on major survival pathways (Meucci and Miller, 1996; Meucci et al, 1998, 2000). Chemokines, including SDF- $1 \mu$, are able to rescue hippocampal neurons from the apoptosis induced by gp $120_{\text {IIIB }}$ or by withdrawal of glial trophic factors and activate several antiapoptotic pathways, such as inositol triphosphate kinase (PI3$\mathrm{K}) / \mathrm{Akt}$ and NF- $\mu \mathrm{B}$ in these neurons (Meucci and Miller, 1996; Meucci et al, 1998, 2000). Our data so far indicate that low levels of phosphorylated $\mathrm{Rb}$ are normally found in the nucleus of hippocampal neurons under control conditions (i.e., in the presence of trophic factors), and that SDF-1 $\mu$ regulates Rb and E2F-1 in a similar manner to granule neurons (Figure 8). SDF-1 $\mu$ also reduced the increase of $\mathrm{Rb}$ phosphorylation induced by trophic factors withdrawal, whereas gp $120_{\text {IIIB }}$ was ineffective in these conditions and increased Rb phosphorylation when neurons were treated in their glia-conditioned medium (data not shown). In addition, we found that gp $120_{\text {IIIB }}$ also increased the DNA-binding activity of E2F-1 in hippocampal neurons (Figure 8B), suggesting a novel potential role of cell-cycle proteins in HIV neuropathogenesis. However, whether activation of E2F-1 is required for gp120 neurotoxicity still remains to be determined.

\section{Discussion}

Several studies have recently suggested that, beyond their classical involvement in neuroinflammatory and infectious processes, chemokines may play additional roles in the CNS, such as regulation of neuronal survival, differentiation, synaptic transmission, and plasticity (Meucci et al, 1998; Asensio and Campbell, 1999; Limatola et al, 2000; Bezzi et al, 2001; Lu et al, 2002; Stumm et al, 2002). In analogy to what is observed in hematopoietic cells (Broxmeyer et al, 2001), emerging data indicate that SDF-1 $\mu$ can regulate proliferation and maturation of developing neurons (Zou et al, 1998; Klein et al, 2001; Lu et al, 2002). For 
instance, SDF- $1 \mu$ contributes to the maintenance of the external granule cell layer (EGL) in the cerebellum by localizing granule cells to the EGL and enhancing the activity of Sonic hedgehog (Klein et al, 2001; Zhu et al, 2002). One of the effects of SDF-1 $\mu$ in primitive hematopoietic cells is the regulation of cell-cycle progression. As recently reported by different groups, SDF-1 $\mu$ selectively and reversibly blocks S-phase entry of quiescent erythroid and granulopoietic colony forming cells, and promotes survival of CD34 ${ }^{+}$cells via a PI3-K/Aktdependent pathway (Vicente-Manzanares et al, 1999; Cashman et al, 2002; Lataillade et al, 2002).

We had previously shown that chemokines-including SDF-1 $\mu$-regulate a number of intracellular pathways in neurons, leading to activation of Akt and other prosurvival factors, such as NF- $\mu \mathrm{B}$ and CREB (Meucci et al, 1998, 2000). Akt also regulates the activity of cellcycle proteins and transcription factors (i.e., Mdm2, p53) involved in cell-cycle progression (Yamaguchi et al, 2001; Gottlieb et al, 2002; Sears and Nevins, 2002). Thus, we hypothesized that chemokine receptors may contribute to neuronal survival and differentiation by maintaining neurons in a quiescent state. To test this hypothesis, we have studied the effect of $\mathrm{SDF}-1 \mu$ on $\mathrm{Rb}$ and E2F-1, two major regulators of cell-cycle progression, differentiation, and apoptosis.

The data presented here show that activation of CXCR4 by SDF- $1 \mu$ up-regulates Rb expression, as indicated by experiments with rat primary neuronal cultures and human cell lines.

$\mathrm{SDF}-1 \mu$ also affects the phosphorylation state and subcellular localization of $\mathrm{Rb}$ in a way that promotes the ability of this protein to block the transcriptional activity of E2F-1. This is supported by the diminished DNA-binding activity of E2F-1 in cells or neurons treated with SDF- $1 \mu$ and by the neuroprotective action of SDF- $1 \mu$ in cerebellar granule cultures deprived of depolarizing concentrations of extracellular $\mathrm{K}^{+}$. In fact, overactivation of E2F-1, resulting from the functional loss of $\mathrm{Rb}$, is primarily responsible for the neuronal death in these experimental conditions (Padmanabhan et al, 1999; O'Hare et al, 2000). As deregulation of cell-cycle proteins has been implicated in different in vitro and in vivo models of neurodegeneration, we believe this may represent a novel general mechanism whereby chemokines affect neuronal survival and differentiation, which could be altered in neuropathological conditions. Of note in this regard is the recent discovery that alterations of the expression and localization of cell-cycle proteins (Rb, E2F-1, and p53) have been found in the brain of HIV-demented patients (Jordan-Sciutto et al, 2002), suggesting their involvement in HIV neuropathogenesis. Although this is still a matter of investigation, our preliminary data with the HIV envelope protein gp120 IIIB would support this conclusion; in contrast to SDF-1 $\mu$, gp $120_{\text {IIIB }}$ does not prevent the Rb loss and phosphorylation induced by $\mathrm{K}^{+}$deprivation in cerebellar granule neurons, whereas it increases E2F-1-binding activity under normal conditions. Interestingly, gp120 $0_{\mathrm{III}}$ does not enhance the neurotoxicity or Rb phosphorylation induced by $\mathrm{K} 5$. Thus, the inappropriate activation of the $\mathrm{CDK} / \mathrm{Rb} / \mathrm{E} 2 \mathrm{~F}-1$ pathway could be implicated in HIV-induced neuronal damage. Whether this turns to be the case or not, the ability of SDF-and possibly other chemokines - to promote the neuronal "resting" state provides an interesting setting for studying the multiple (sometimes contradictory) roles of these proteins in the CNS, and could account for a variety of effects exerted by chemokines on developing and mature neurons. However, further investigation is needed to identify the mechanisms of action involved and, more importantly, to verify the relevance of these effects in vivo. Our data so far, show that de novo protein synthesis is required for the effect of SDF- $1 \mu$ on total $\mathrm{Rb}$, and suggest that SDF-1 $\mu$ might reduce the level of phosphoRb either by inhibiting upstream kinase(s) (i.e., CDK4) or by promoting the activity of protein phosphatases. In addition, activation of CXCR4 might also be coupled to mechanisms that regulate $\mathrm{Rb}$ translocation to and from the nucleus, as suggested by the experiments with HOS deprived of serum in the presence and in the absence of SDF- $1 \mu$. 
In conclusion, our findings indicate that SDF- $1 \mu$ is able to affect the expression and activity of $\mathrm{Rb}$ and E2F-1 in differentiated neurons, suggesting that the action of the chemokine on neuronal survival may be related to its ability of interfering with the transcription of genes regulated by E2F-1. Alternatively, SDF- $1 \mu$ may affect the interaction of Rb and/or E2F-1 with other proteins implicated in cell survival and apoptosis (i.e., Mdm2, p53), an issue we are currently investigating. Thus, the inappropriate activation of CXCR4 by viral-derived proteins - or by SDF- $1 \mu$ under pathological conditions-may contribute to neuronal dysfunction in patients with acquired immunodeficiency syndrome (AIDS) and other neuroinflammatory diseases.

\section{Materials and methods}

\section{Cell cultures}

Neurons-Primary cultures of cerebellar or hippocampal rat neurons were cultured as previously described (Galli et al, 1995; Meucci et al, 1998, 2000) with minor modifications. Briefly, (a) cerebellar granule neurons were obtained from the cerebella of 7- to 8-day-old rats and rapidly collected in a culture dish containing ice-cold dissection medium. After removing the meninges, tissue was minced, incubated with $0.25 \%$ trypsin for 15 to 20 min and dissociated with a flame-narrowed pipette. Cells were plated onto polylysine-coated (100 $\mu \mathrm{g} /$ $\mathrm{ml})$ dishes $\left(4 \times 10^{6}\right.$ cells $/ 60$-mm dish) or coverslips $\left(5 \times 10^{5}\right.$ cells $/ 15$-mm coverslip) in basal Eagle medium supplemented with $\mathrm{KCl}$ (final concentration $25 \mathrm{mM}$ ), $10 \%$ fetal calf serum, 2 $\mathrm{mM}$ glutamine, and $100 \mu \mathrm{g} / \mathrm{ml}$ gentamycin. Cytosine- $\mu$-D-arabinofuranoside $(10 \mu \mathrm{M})$ was added to the culture 18 to $20 \mathrm{~h}$ after plating to halt proliferation of non-neuronal cells. (b) Hippocampal neurons were obtained from the brain of 17- to 18-day-old rat embryos and cultured in serum-free medium using the bilaminar cell culture system, as previously described (Meucci and Miller, 1996; Meucci et al, 1998, 2000). A feeder layer of secondary astrocytes supported the growth and differentiation of the pure neuronal layer. Neurons were separated from glia immediately before the experiments, unless otherwise specified.

HOS cells-HOS.CXCR4 cells were maintained in Dulbecco's minimum essential medium (DMEM) containing $10 \%$ fetal calf serum and $1 \mu \mathrm{g} / \mathrm{ml}$ puromycin. These cells were obtained through the AIDS Research and Reference Program, Division of AIDS, National Institute of Allergy and Infectious Diseases, National Institutes of Health (from Dr. Nathaniel Landau) and are CD4 negative (Landau and Littman, 1992; Deng et al, 1996).

\section{Western blots}

After treatment, cells were washed with ice-cold balanced salt solution and scraped in lysis buffer (25 mM Tris, $150 \mathrm{mM} \mathrm{NaCl}, 5 \mathrm{mM} \mathrm{NaF}, 1 \mathrm{mM}$ EDTA, $1 \mathrm{mM}$ DTT, $1 \%$ Nonidet P-40, $5 \mu \mathrm{g}$ each of aprotinin, leupeptin, and pepstatin, $1 \mathrm{mM} 4$-(2-aminoethyl)benzeresulfonyl fluoride HCE (AEBSF), $1 \mathrm{mM}$ vanadate. A lower concentration of detergent $(0.1 \%)$ was used for the extraction of cytosolic proteins when they had to be separated from nuclear proteins, and the pellet was further processed with a hyperosmotic buffer as previously described (Meucci et al, 1998, 2000). Histone-1 was used as a nuclear marker and to verify the absence of nuclear proteins in the cytosolic extracts. The protein concentration in cell lysates was determined by bicinchoninic acid protein assay from Pierce. $\mu$-Actin expression was assessed to confirm equal sample loading and possible changes in constitutive proteins during apoptosis. Proteins were resolved by sodium dodecyl sulfate-polyacrylamide gel electrophoresis (SDSPAGE) and transferred to polyvinylidene fluoride (PVDF) membranes for immunoblotting. The following primary antibodies were used: anti-Rb (monoclonal G3-245 at 1:4000; Pharmingen), ppRb (Ser795 or Ser780 at 1:2000; Cell Signalling Technology), E2F-1 (either a monoclonal, KH95, or the polyclonal antibody C20 at 1:2000 and 1:500, respectively; Santa Cruz Technology), $\mu$-Actin (polyclonal antibody at 1:5000; Sigma-Aldrich), histone-1 
(polyclonal antibody FL-219 at 1:500; Santa Cruz Technology). An image acquisition and analysis system from BioRad (ChemiDoc System) as well as the U-Scan software were used for detection of chemiluninescent bands and densitometric analysis.

\section{Immunocytochemistry}

Cells were fixed in 4\% paraformaldehyde. The anti- $\mathrm{Rb}$ (1:500; Pharmingen) and antiphosphoRb (Ser795, 1:100; Cell Signalling Technology) were followed by a biotinylated secondary antibody and streptavidin conjugated with $\mathrm{Cy} 2$ or Cy3. The antibody against CXCR4 (sc-9046; Santa Cruz Biotechnology) was used at a dilution of 1:50. As this antibody recognizes an internal region of the receptor, cells were previously permeabilized with $0.1 \%$ Triton $\times 100$. Cells were also stained for the neuronal specific markerg $\mu$-tubulin III (1:500; Covance, Berkley, CA). Secondary antibodies conjugated to either AlexaFluor546 (1:1000; Molecular Probes) or Cy2 (1:500; Jackson Immunoresearch Labs) were used for CXCR4 and $\mu$-tubulin III staining, respectively. Nuclear counterstaining was obtained with Hoechst 33342 $(3 \mu \mathrm{g} / \mathrm{ml})$. The cells were mounted and observed under an epifluorescent microscope (Olympus IX70) connected to a CCD (Micromax), and images were acquired using the software Metamorph (Universal Imaging) (Meucci et al, 2000).

\section{In vitro kinase assay}

A GST-Rb fusion protein (amino acids 769 to 921 of mouse Rb; Santa Cruz Biotechnology) was used as substrate for the in vitro reactions after binding to glutathione beads. The reaction buffer contained $50 \mathrm{mM}$ Tris, pH 7.4, $10 \mathrm{mM} \mathrm{MgCl}_{2}$, and $5 \mathrm{mM} \mathrm{DTT}$. GST-Rb $(0.5 \mu \mathrm{g} / \mathrm{sample})$ was incubated with cytosolic extracts $(10 \mu \mathrm{g})$ for $30 \mathrm{~min}$ at $30^{\circ} \mathrm{C}$ in the presence of $5 \mu \mathrm{Ci}$ $\left[\mu-{ }^{32} \mathrm{P}\right]-\mathrm{ATP}$ and $10 \mu \mathrm{M}$ ATP. Incubations were stopped by placing tubes in ice. Samples were immediately centrifuged $\left(\right.$ at $\left.4^{\circ} \mathrm{C}\right)$ to pellet $\mathrm{Rb} /$ beads. Pellets were washed, resuspended in sample buffer, boiled, and separated by electrophoresis. Then they were transferred to a nitrocellulose membrane and visualized by autoradiography.

\section{Electromobility shift assay (EMSA)}

Nuclear (HOS) or total (neurons) extracts $(1.5 \mu \mathrm{g})$ were incubated with $0.25 \mu \mathrm{g} / \mu \mathrm{l}$ of $3^{\prime}$ biotinylated oligonucleotides containing a consensus-binding site for E2F-1 (5'-

ATTTAAGTTTCGCGCCCTTTCTCAA-3'). After a 20-min incubation at room temperature, the samples were resolved in a $6 \%$ nondenaturing PAGE. Streptavidin-horseradish peroxidase conjugate and the chemiluminescent substrates were provided with the LightShift (EMSA) kit (Pierce).

\section{Survival assay}

Neuronal survival studies were performed as previously described using different fluorescent dyes (fluorescein diacetate, propidium iodide, and Hoechst 33342) (Meucci and Miller, 1996; Meucci et al, 1998, 2000). Cerebellar granule neurons were cultured in the presence of serum and high potassium $(25 \mathrm{mM})$ for the first week and then switched to low-potassium (5 $\mathrm{mM}$ ) medium to induce apoptosis, in the presence or absence of SDF- $1 \mu$ and/or other drugs. Neuronal viability was assessed 18 to $24 \mathrm{~h}$ later.

\section{Statistical analysis}

Data are reported as mean \pm SEM with sample size for each experiment. One-way analysis of variance (ANOVA), followed by Newman-Keuls multiple-comparison procedure, was used for analysis of survival experiments. Paired $t$ test was used to compare differences in the band densities of immunoblots. Analysis of immunostaining was performed using the software Metamorph. 


\section{Materials}

Unless otherwise specified, tissue culture media are from Life Technology and other general reagents are from Sigma. SDF-1 $\mu$ was purchased from R\&D System. The lyophilized protein was reconstituted $(100 \mu \mathrm{g} / \mathrm{ml})$ in $0.1 \%$ bovine serum albumin/phosphate-buffered saline (BSA/ PBS) and aliquots stored at $-20^{\circ} \mathrm{C}$. Recombinant HIV-1 $1_{\text {IIIB }}$ gp120 from Intracel Corporation was prepared and stored as previously described (Meucci et al, 1998, 2000). Custom modified oligonucleotides were obtained from Qiagen.

\section{Acknowledgements}

This work was supported by grants from the NIH/NIDA (R01 DA15014-01) and the American Foundation of AIDS Research (amfAR 02816-30-RG) to OM. The authors are grateful to Dr. Peter Toogood (Pfizer Inc., Ann Arbor, MI), who generously provided the compound PD0183812, and wish to thank Dr. Todd Pappas (UTMB, Galveston, TX) for kindly sharing AMD3100.

\section{References}

Asensio VC, Campbell IL. Chemokines in the CNS: plurifunctional mediators in diverse states. Trends Neurosci 1999;22:504-512. [PubMed: 10529818]

Asensio VC, Campbell IL. Chemokines and viral diseases of the central nervous system. Adv Virus Res 2001;56:127-173. [PubMed: 11450298]

Bajetto A, Bonavia R, Barbero S, Piccioli P, Costa A, Florio T, Schettini G. Glial and neuronal cells express functional chemokine receptor CXCR4 and its natural ligand stromal cell-derived factor 1 . J Neurochem 1999;73:2348-2357. [PubMed: 10582593]

Bezzi P, Domercq M, Brambilla L, Galli R, Schols D, De Clercq E, Vescovi A, Bagetta G, Kollias G, Meldolesi J, Volterra A. CXCR4-activated astrocyte glutamate release via TNFalpha: amplification by microglia triggers neurotoxicity. Nat Neurosci 2001;4:702-710. [PubMed: 11426226]

Boutillier AL, Kienlen-Campard P, Loeffler JP. Depolarization regulates cyclin D1 degradation and neuronal apoptosis: a hypothesis about the role of the ubiquitin/proteasome signalling pathway. Eur J Neurosci 1999;11:441-448. [PubMed: 10051745]

Broxmeyer HE, Youn BS, Kim C, Hangoc G, Cooper S, Mantel C. Chemokine regulation of hematopoiesis and the involvement of pertussis toxin-sensitive $G$ alpha i proteins. Ann N Y Acad Sci 2001;938:117-127. [PubMed: 11458498]discussion 127-118

Cashman J, Clark-Lewis I, Eaves A, Eaves C. Stromal-derived factor 1 inhibits the cycling of very primitive human hematopoietic cells in vitro and in NOD/SCID mice. Blood 2002;99:792-799. [PubMed: 11806978]

Deng H, Liu R, Ellmeier W, Choe S, Unutmaz D, Burkhart M, Di Marzio P, Marmon S, Sutton RE, Hill CM, Davis CB, Peiper SC, Schall TJ, Littman DR, Landau NR. Identification of a major co-receptor for primary isolates of HIV-1. Nature 1996;381:661-666. [PubMed: 8649511]

D'Mello SR, Galli C, Ciotti T, Calissano P. Induction of apoptosis in cerebellar granule neurons by low potassium: inhibition of death by insulin-like growth factor I and cAMP. Proc Natl Acad Sci USA 1993;90:10989-10993. [PubMed: 8248201]

Dyson N. The regulation of E2F by pRB-family proteins. Genes Dev 1998;12:2245-2262. [PubMed: 9694791]

Feng Y, Broder CC, Kennedy PE, Berger EA. HIV-1 entry cofactor: functional cDNA cloning of a seventransmembrane, G protein-coupled receptor. Science 1996;272:872-877. [PubMed: 8629022]

Fry DW, Bedford DC, Harvey PH, Fritsch A, Keller PR, Wu Z, Dobrusin E, Leopold WR, Fattaey A, Garrett MD. Cell cycle and biochemical effects of PD 0183812. A potent inhibitor of the cyclin Ddependent kinases CDK4 and CDK6. J Biol Chem 2001;276:16617-16623. [PubMed: 11278443]

Galli C, Meucci O, Scorziello A, Werge TM, Calissano P, Schettini G. Apoptosis in cerebellar granule cells is blocked by high $\mathrm{KCl}$, forskolin, and IGF-1 through distinct mechanisms of action: the involvement of intracellular calcium and RNA synthesis. J Neurosci 1995;15:1172-1179. [PubMed: 7532699] 
Garden GA, Budd SL, Tsai E, Hanson L, Kaul M, D'Emilia DM, Friedlander RM, Yuan J, Masliah E, Lipton SA. Caspase cascades in human immunodeficiency virus-associated neurodegeneration. J Neurosci 2002;22:4015-4024. [PubMed: 12019321]

Giovanni A, Keramaris E, Morris EJ, Hou ST, O'Hare M, Dyson N, Robertson GS, Slack RS, Park DS. E2F1 mediates death of B-amyloid-treated cortical neurons in a manner independent of p53 and dependent on Bax and caspase 3. J Biol Chem 2000;275:11553-11560. [PubMed: 10766769]

Gottlieb TM, Leal JF, Seger R, Taya Y, Oren M. Cross-talk between Akt, p53 and Mdm2: possible implications for the regulation of apoptosis. Oncogene 2002;21:1299-1303. [PubMed: 11850850]

Harbour JW, Dean DC. Rb function in cell-cycle regulation and apoptosis. Nat Cell Biol 2000a;2:E65E67. [PubMed: 10783254]

Harbour JW, Dean DC. The Rb/E2F pathway: expanding roles and emerging paradigms. Genes Dev 2000b;14:2393-2409. [PubMed: 11018009]

Hesselgesser J, Horuk R. Chemokine and chemokine receptor expression in the central nervous system. J Neuro Virol 1999;5:13-26.

Hesselgesser J, Taub D, Baskar P, Greenberg M, Hoxie J, Kolson DL, Horuk R. Neuronal apoptosis induced by HIV-1 gp120 and the chemokine SDF-1 alpha is mediated by the chemokine receptor CXCR4. Curr Biol 1998;8:595-598. [PubMed: 9601645]

Jacks T, Fazeli A, Schmitt EM, Bronson RT, Goodell MA, Weinberg RA. Effects of an Rb mutation in the mouse. Nature 1992;359:295-300. [PubMed: 1406933]

Jordan-Sciutto KL, Wang G, Murphy-Corb M, Wiley CA. Induction of cell-cycle regulators in simian immunodeficiency virus encephalitis. Am J Pathol 2000;157:497-507. [PubMed: 10934153]

Jordan-Sciutto KL, Wang G, Murphey-Corb M, Wiley CA. Cell cycle proteins exhibit altered expression patterns in lentiviral-associated encephalitis. J Neurosci 2002;22:2185-2195. [PubMed: 11896158]

Kaul M, Garden GA, Lipton SA. Pathways to neuronal injury and apoptosis in HIV-associated dementia. Nature 2001;410:988-994. [PubMed: 11309629]

Kaul M, Lipton SA. Chemokines and activated macrophages in HIV gp120-induced neuronal apoptosis. Proc Natl Acad Sci USA 1999;96:8212-8216. [PubMed: 10393974]

Klein RS, Rubin JB, Gibson HD, DeHaan EN, Alvarez-Hernandez X, Segal RA, Luster AD. SDF-1 alpha induces chemotaxis and enhances Sonic hedgehog-induced proliferation of cerebellar granule cells. Development 2001;128:1971-1981. [PubMed: 11493520]

Landau NR, Littman DR. Packaging system for rapid production of murine leukemia virus vectors with variable tropism. J Virol 1992;66:5110-5113. [PubMed: 1321291]

Lataillade JJ, Clay D, Bourin P, Herodin F, Dupuy C, Jasmin C, Bousse-Kerdiles MC. Stromal cellderived factor 1 regulates primitive hematopoiesis by suppressing apoptosis and by promoting $\mathrm{G}(0) /$ $\mathrm{G}(1)$ transition in CD34(+) cells: evidence for an autocrine/paracrine mechanism. Blood 2002;99:1117-1129. [PubMed: 11830456]

Limatola C, Giovannelli A, Maggi L, Ragozzino D, Castellani L, Ciotti MT, Vacca F, Mercanti D, Santoni A, Eusebi F. SDF-1alpha-mediated modulation of synaptic transmission in rat cerebellum. Eur J Neurosci 2000;12:2497-2504. [PubMed: 10947825]

Lu M, Grove EA, Miller RJ. Abnormal development of the hippocampal dentate gyrus in mice lacking the CXCR4 chemokine receptor. Proc Natl Acad Sci USA 2002;99:7090-7095. [PubMed: 11983855]

Lu Q, Sun EE, Klein RS, Flanagan JG. Ephrin-B reverse signaling is mediated by a novel PDZ-RGS protein and selectively inhibits G protein-coupled chemoattraction. Cell 2001;105:69-79. [PubMed: 11301003]

Ma Q, Jones D, Borghesani PR, Segal RA, Nagasawa T, Kishimoto T, Bronson RT, Springer TA. Impaired B-lymphopoiesis, myelopoiesis, and derailed cerebellar neuron migration in CXCR4- and SDF-1-deficient mice. Proc Natl Acad Sci USA 1998;95:9448-9453. [PubMed: 9689100]

Macleod K. pRb and E2f-1 in mouse development and tumorigenesis. Curr Opin Genet Dev 1999;9:3139. [PubMed: 10072353]

Meucci O, Fatatis A, Simen AA, Bushell TJ, Gray PW, Miller RJ. Chemokines regulate hippocampal neuronal signaling and gp120 neurotoxicity. Proc Natl Acad Sci USA 1998;95:14500-14505. [PubMed: 9826729]

Meucci O, Fatatis A, Simen AA, Miller RJ. Expression of CX3CR1 chemokine receptors on neurons and their role in neuronal survival. Proc Natl Acad Sci USA 2000;97:8075-8080. [PubMed: 10869418] 
Meucci O, Miller RJ. gp120-induced neurotoxicity in hippocampal pyramidal neuron cultures: protective action of TGF-beta1. J Neurosci 1996;16:4080-4088. [PubMed: 8753870]

Miller RJ, Meucci O. AIDS and the brain: is there a chemokine connection? Trends Neurosci 1999;22:471-479. [PubMed: 10481195]

Moroni MC, Hickman ES, Denchi EL, Caprara G, Colli E, Cecconi F, Muller H, Helin K. Apaf-1 is a transcriptional target for E2F and p53. Nat Cell Biol 2001;3:552-558. [PubMed: 11389439]

O'Hare MJ, Hou ST, Morris EJ, Cregan SP, Xu Q, Slack RS, Park DS. Induction and modulation of cerebellar granule neuron death by E2F-1. J Biol Chem 2000;275:25358-25364. [PubMed: 10851232]

Osuga H, Osuga S, Wang F, Fetni R, Hogan MJ, Slack RS, Hakim AM, Ikeda JE, Park DS. Cyclindependent kinases as a therapeutic target for stroke. Proc Natl Acad Sci USA 2000;97:10254-10259. [PubMed: 10944192]

Padmanabhan J, Park DS, Greene LA, Shelanski ML. Role of cell cycle regulatory proteins in cerebellar granule neuron apoptosis. J Neurosci 1999;19:8747-8756. [PubMed: 10516294]

Park DS, Morris EJ, Bremner R, Keramaris E, Padmanabhan J, Rosenbaum M, Shelanski ML, Geller $\mathrm{HM}$, Greene LA. Involvement of retinoblastoma family members and E2F/DP complexes in the death of neurons evoked by DNA damage. J Neurosci 2000;20:3104-3114. [PubMed: 10777774]

Phillips AC, Ernst MK, Bates S, Rice NR, Vousden KH. E2F-1 potentiates cell death by blocking antiapoptotic signaling pathways. Mol Cell 1999;4:771-781. [PubMed: 10619024]

Ransohoff RM, Tani M, Glabinski AR, Chernosky A, Krivacic K, Peterson JW, Chien HF, Trapp BD. Chemokines and chemokine receptors in model neurological pathologies: molecular and immunocytochemical approaches. Methods Enzymol 1997;287:319-348. [PubMed: 9330331]

Savio T, Levi G. Neurotoxicity of HIV coat protein gp120, NMDA receptors, and protein kinase C: a study with rat cerebellar granule cell cultures PG-265-72. J Neurosci Res 1993;34:265-272. [PubMed: 7681115]

Sears RC, Nevins JR. Signaling networks that link cell proliferation and cell fate. J Biol Chem 2002;277:11617-11620. [PubMed: 11805123]

Stumm RK, Rummel J, Junker V, Culmsee C, Pfeiffer M, Krieglstein J, Hollt V, Schulz S. A dual role for the SDF-1/CXCR4 chemokine receptor system in adult brain: isoform-selective regulation of SDF-1 expression modulates CXCR4-dependent neuronal plasticity and cerebral leukocyte recruitment after focal ischemia. J Neurosci 2002;22:5865-5878. [PubMed: 12122049]

Taya Y. RB kinases and RB-binding proteins: new points of view. Trends Biochem Sci 1997;22:14-17. [PubMed: 9020586]

Tham TN, Lazarini F, Franceschini IA, Lachapelle F, Amara A, Dubois-Dalcq M. Developmental pattern of expression of the alpha chemokine stromal cell-derived factor 1 in the rat central nervous system. Eur J Neurosci 2001;13:845-856. [PubMed: 11264658]

Trinh E, Boutillier AL, Loeffler JP. Regulation of the retinoblastoma-dependent Mdm2 and E2F-1 signaling pathways during neuronal apoptosis. Mol Cell Neurosci 2001;17:342-353. [PubMed: 11178871]

Van Der Meer P, Goldberg SH, Fung KM, Sharer LR, Gonzalez-Scarano F, Lavi E. Expression pattern of CXCR3, CXCR4, and CCR3 chemokine receptors in the developing human brain. J Neuropathol Exp Neurol 2001;60:25-32. [PubMed: 11202173]

Vicente-Manzanares M, Rey M, Jones DR, Sancho D, Mellado M, Rodriguez-Frade JM, del Pozo MA, Yanez-Mo M, de Ana AM, Martinez AC, Merida I, Sanchez-Madrid F. Involvement of phosphatidylinositol 3-kinase in stromal cell-derived factor-1 alpha-induced lymphocyte polarization and chemotaxis. J Immunol 1999;163:4001-4012. [PubMed: 10491003]

Yamaguchi A, Tamatani M, Matsuzaki H, Namikawa K, Kiyama H, Vitek MP, Mitsuda N, Tohyama M. Akt activation protects hippocampal neurons from apoptosis by inhibiting transcriptional activity of p53. J Biol Chem 2001;276:5256-5264. [PubMed: 11054421]

Zacksenhaus E, Jiang Z, Hei YJ, Phillips RA, Gallie BL. Nuclear localization conferred by the pocket domain of the retinoblastoma gene product. Biochim Biophys Acta 1999;1451:288-296. [PubMed: 10556583]

Zacksenhaus E, Jiang Z, Phillips RA, Gallie BL. Dual mechanisms of repression of E2F1 activity by the retinoblastoma gene product. EMBO J 1996;15:5917-5927. [PubMed: 8918469] 
Zheng L, Lee WH. The retinoblastoma gene: a prototypic and multifunctional tumor suppressor. Exp Cell Res 2001;264:2-18. [PubMed: 11237519]

Zheng J, Thylin MR, Ghorpade A, Xiong H, Persidsky Y, Cotter R, Niemann D, Che D, Zeng YC, Gelbard HA, Shepard RB, Swartz JM, Gendelman HE. Intra-cellular CXCR4 signaling, neuronal apoptosis and neuropathogenic mechanisms of HIV-1-associated dementia. J Neuroimmunol 1999;98:185200. [PubMed: 10430052]

Zhu Y, Yu T, Zhang XC, Nagasawa T, Wu JY, Rao Y. Role of the chemokine SDF-1 as the meningeal attractant for embryonic cerebellar neurons. Nat Neurosci 2002;5:719-720. [PubMed: 12080344]

Zou YR, Kottmann AH, Kuroda M, Taniuchi I, Littman DR. Function of the chemokine receptor CXCR4 in haematopoiesis and in cerebellar development. Nature 1998;393:595-599. [PubMed: 9634238] 


\section{K5}
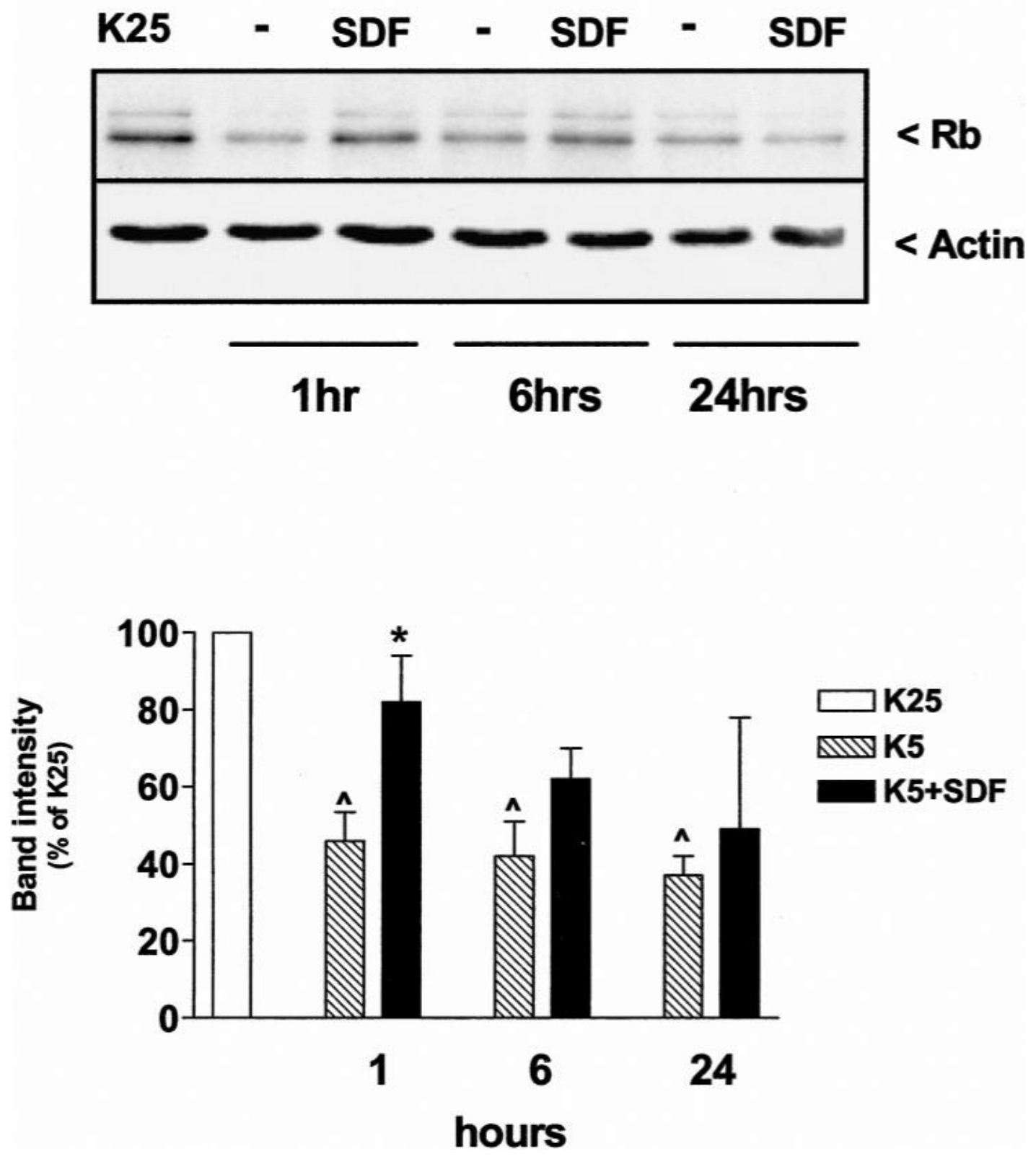

Figure 1.

SDF- $1 \mu$ affects Rb levels in cerebellar granule neurons. Western blot analysis of Rb expression in control neurons (K25) and neurons maintained in K5 medium in the presence or absence of SDF- $1 \mu(20 \mathrm{nM})$ for the indicated time ( $20 \mu \mathrm{g}$ protein/lane). Data reported in the graph (mean \pm SEM) are from three separate experiments. ${ }^{\wedge} P<.05$ versus $\mathrm{K} 25$ and $* P<.05$ versus K5 alone. 

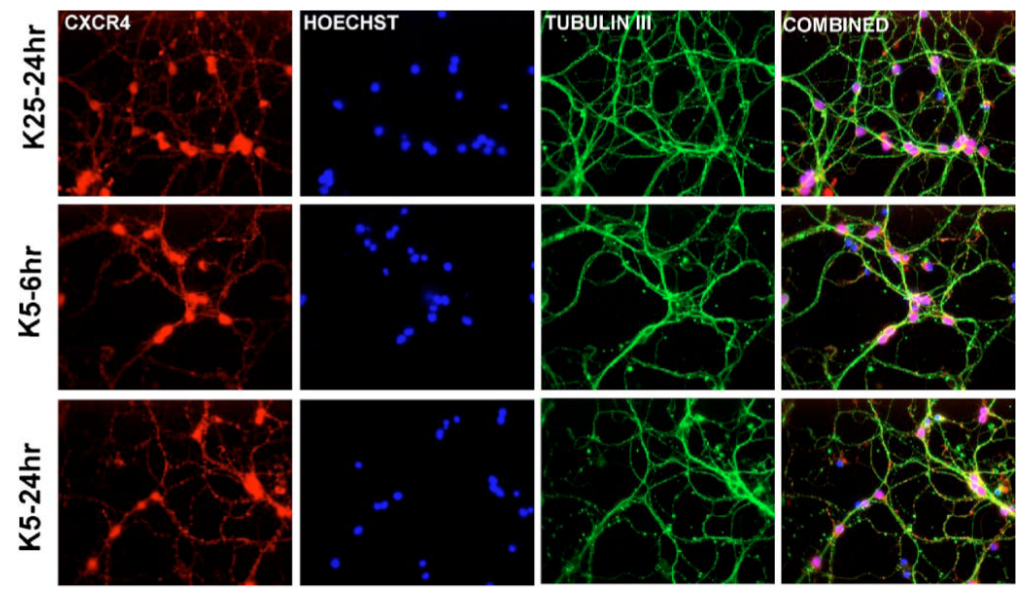

Figure 2.

Expression of CXCR4 in cerebellar granule neurons cultured in high or low potassium. Control neurons (K25) and neurons maintained in K5 for 6 to $24 \mathrm{~h}$ were immunostained with a polyclonal antibody against CXCR4 (amino acids 176 to 293) and a monoclonal antibody for the specific neuronal marker $\mu$-tubulin III (green). Nuclei were stained with Hoechst 33342 (blue). 


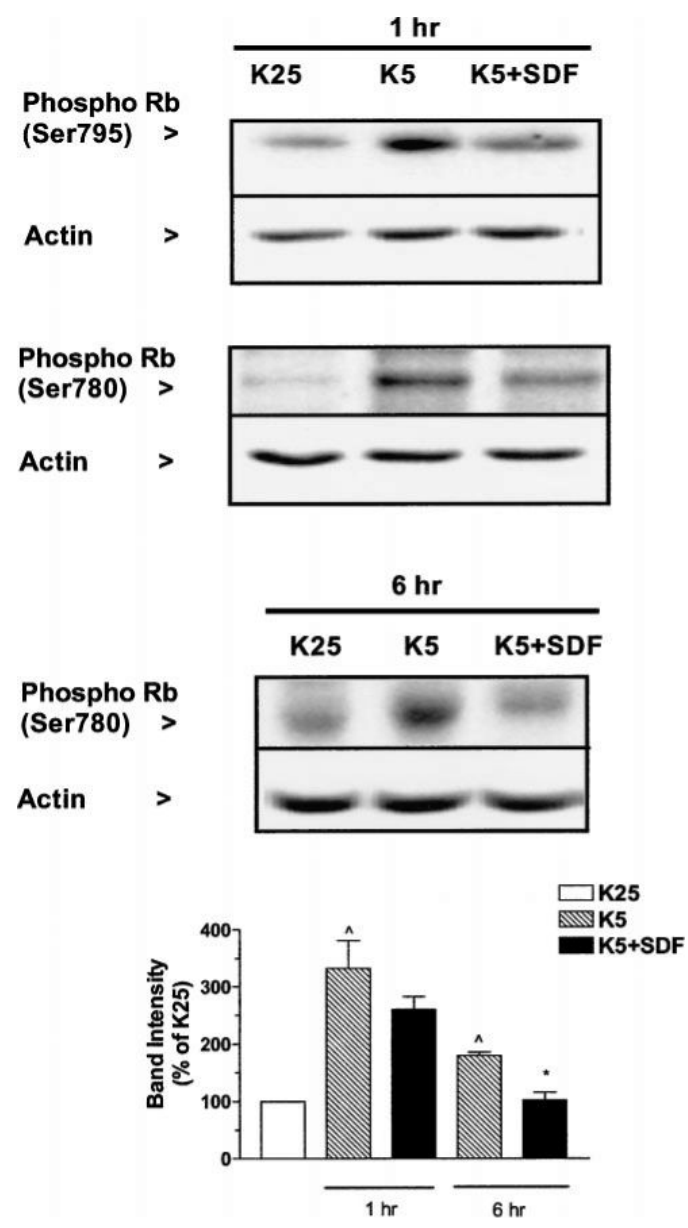

Figure 3.

SDF- $1 \mu$ prevents Rb hyperphosphorylation induced by low potassium. Control neurons (K25) and neurons maintained in K5 medium in the presence or absence of SDF-1 1 (20 nM) for 1 or $6 \mathrm{~h}$ were used to determine variations in the expression of phosphoRb in cerebellar granule neurons by using antibodies for either Ser795pRb or Ser780pRb. Twenty micrograms of protein were loaded in each lane. Data reported in the graph (mean \pm SEM) are from three separate experiments (Ser780pRb). ${ }^{\wedge} P<.05$ versus K25 and $* P<.01$ versus K5. 

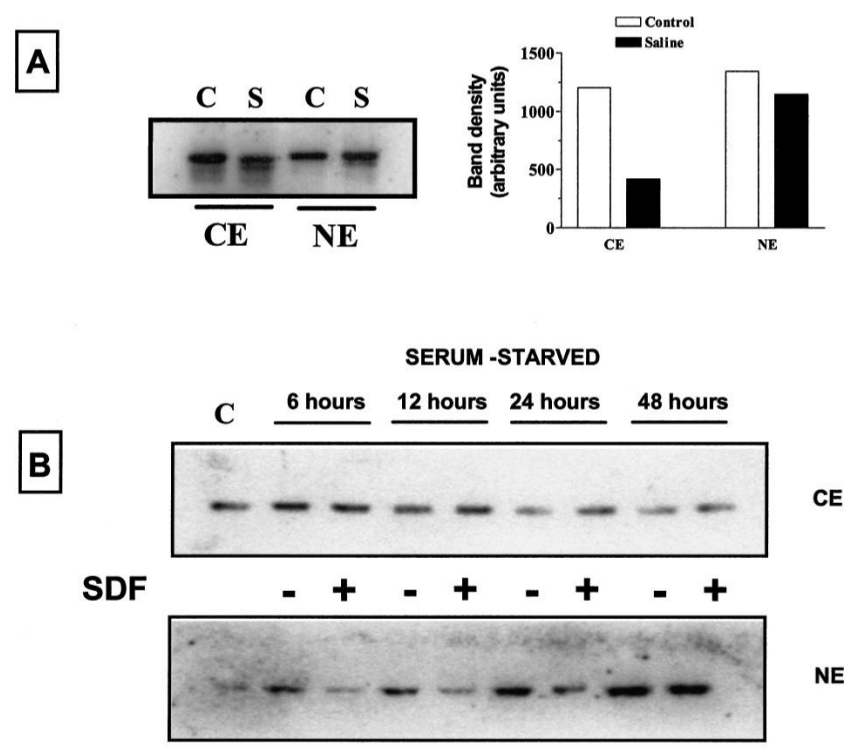

NE
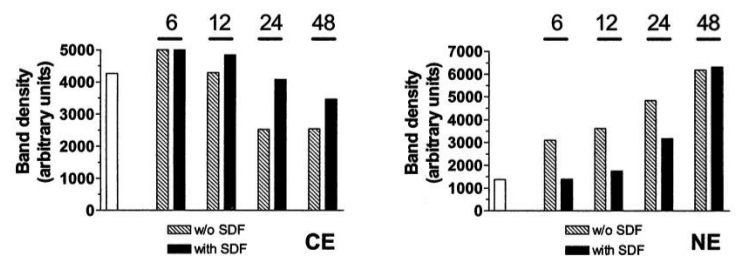

Figure 4.

Effect of SDF- $1 \mu$ on Rb cellular localization in HOS-CXCR4 cells. (A) Cytosolic and nuclear extracts (CE and NE, respectively) were obtained from control cells (C) and cells incubated for $4 \mathrm{~h}$ in saline solution ( $\mathrm{S}$ ). Immunoblots for $\mathrm{Rb}$ show that trophic factors deprivation caused a reduction in the $\mathrm{Rb}$ content mainly at the cytosolic level. (B) SDF-1 $\mu$ prevents changes in $\mathrm{Rb}$ expression and subcellular localization induced by long-term serum starvation. Similar data were obtained from two additional experiments. $(\mathrm{CE}=25 \mu \mathrm{g}$ protein/lane; $\mathrm{NE}=5 \mu \mathrm{g}$ protein/ lane.) 

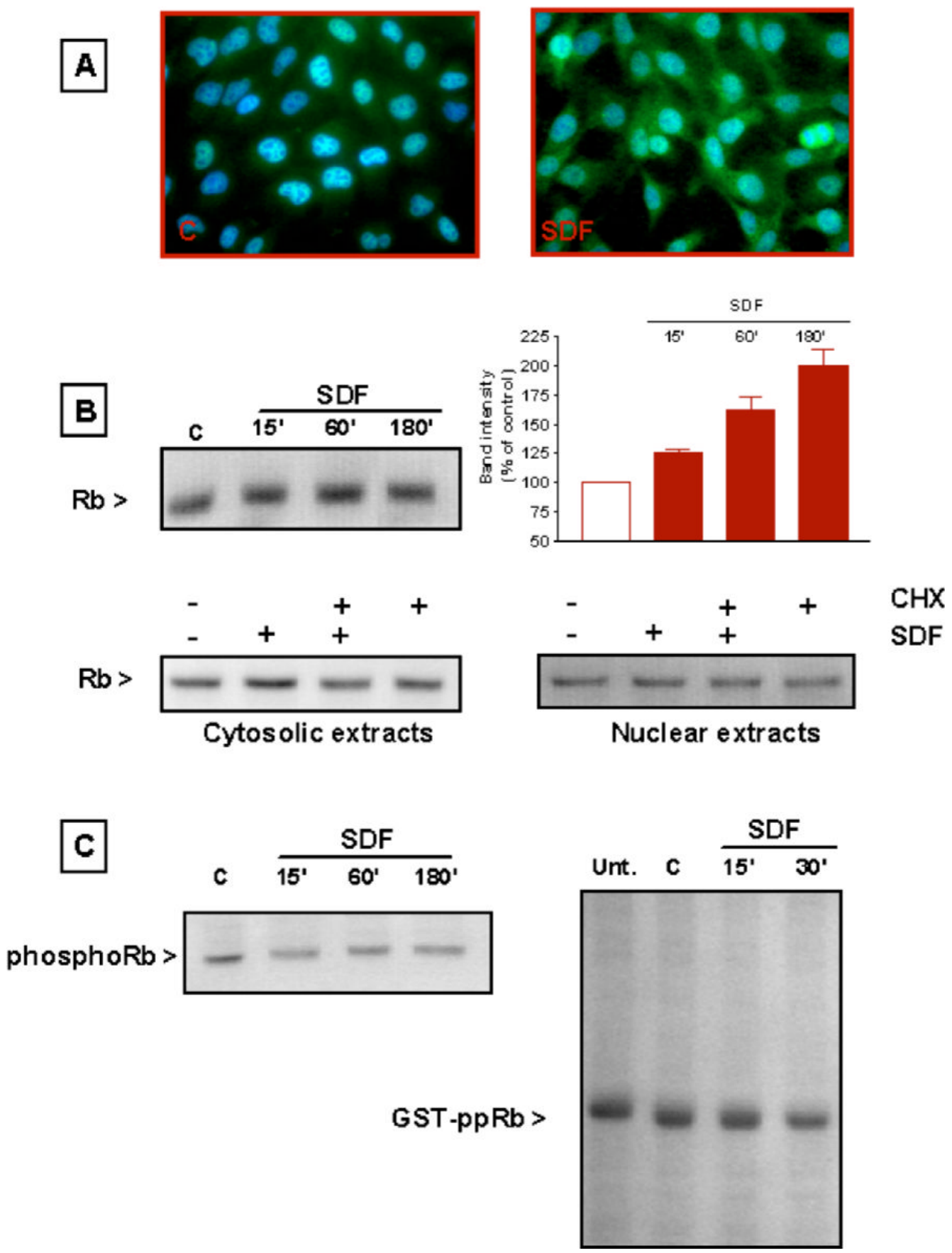

Figure 5.

SDF- $1 \mu$ regulates $\mathrm{Rb}$ expression and phosphorylation in HOS-CXCR4 cells. (A) Immunostaining for $\mathrm{Rb}$ in control cells (left panel) and SDF-treated cells (SDF-1 $\mu 20 \mathrm{nM}, 3-$ $\mathrm{h}$ treatment in regular medium) showing higher levels of $\mathrm{Rb}$ (green) in treated cells. (B) The same antibody was used for immunoblots (SDF-1 $\mu 20 \mathrm{nM}$ ): total cell lysates (top) or cytosolic and nuclear extracts ( $20 \mu \mathrm{g}$ protein/lane). Treatment with CHX prevents the effect of SDF- $1 \mu$ on Rb (bottom). (C) The left panel shows immunoblots for $\mathrm{pRb}$ (Ser795) with the same total cell lysates used in B. In vitro kinase assay showing a reduction in GST-Rb phosphorylation following SDF-1 $\mu(20 \mathrm{nM})$ treatment. 


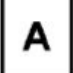

A

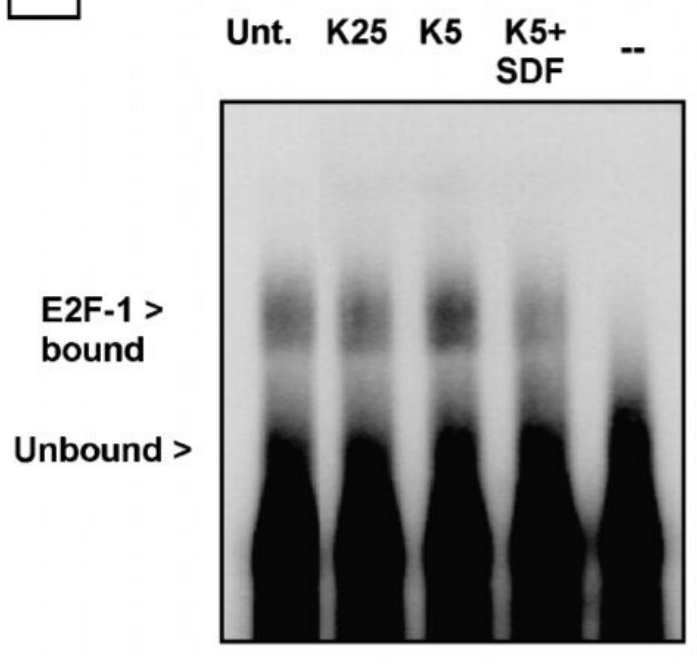

CG

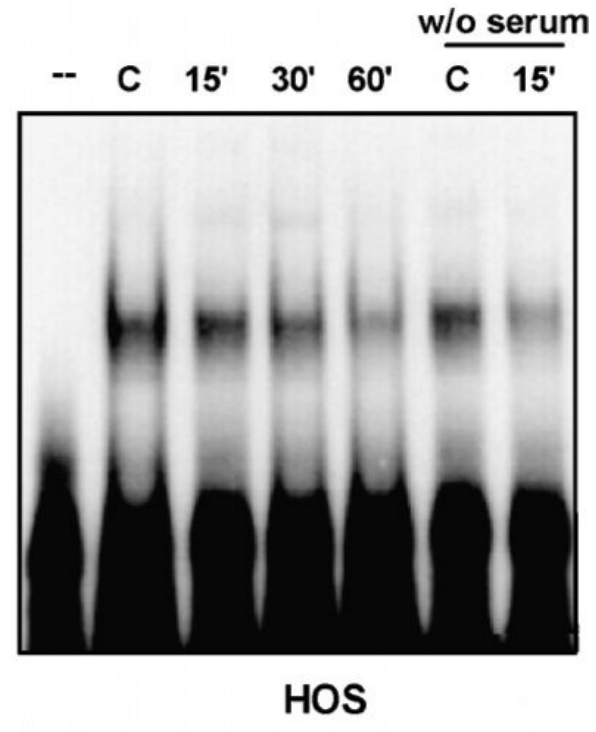

B

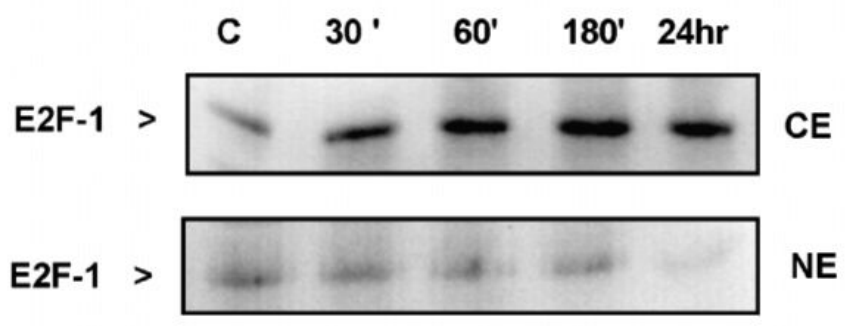

C

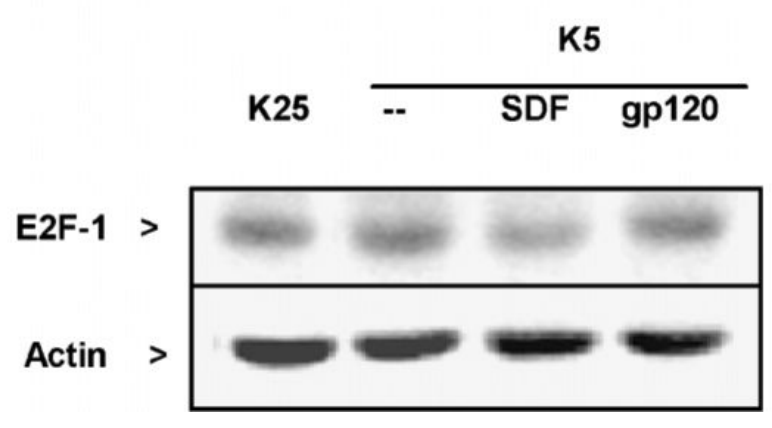

Figure 6.

Effect of SDF-1 $\mu$ on E2F-1 in granule neurons and HOS-CXCR4 cells. (A) SDF-1 $\mu$ prevents the increase in E2F-1 DNA-binding activity induced by $\mathrm{K} 5$ ( $6 \mathrm{~h}$ treatment) in cerebellar granule neurons (left panel). The chemokine also inhibits E2F-1 activity in HOS cells (right panel) in the presence or absence of serum (last two lanes). Lanes marked with (-) do not contain nuclear extracts. (B) Western blot analysis in HOS cells: SDF- $1 \mu(20 \mathrm{nM})$ increases the cytosolic content of E2F-1 and slightly decreases its nuclear level $(\mathrm{CE}=25 \mu \mathrm{g}$ protein/lane; $\mathrm{NE}=5 \mu \mathrm{g}$ protein/lane). (C) Neuronal extracts $(20 \mu \mathrm{g}$ protein/lane) from control and treated cells $(6 \mathrm{~h})$ were immunoblotted with E2F-1 antibody: SDF-1 $\mu$ but not gp120 reduces E2F-1 expression in granule neurons. 

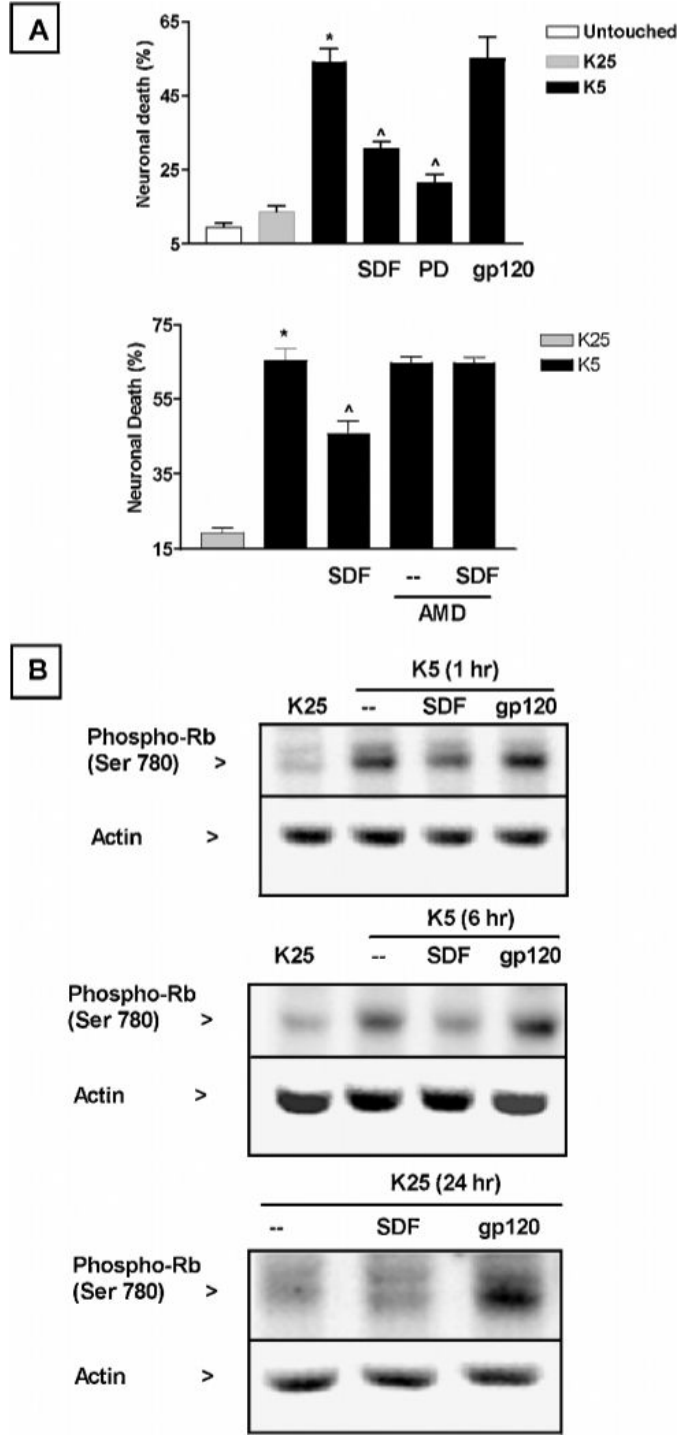

Figure 7.

Effect of SDF-1 $\mu$, PD0183812, and gp120 on granule neurons survival and Rb phosphorylation. (A) Neuronal death induced by potassium deprivation is inhibited by SDF-1 $\mu(20 \mathrm{nM})$ and by PD0183812 $(0.5 \mu \mathrm{M})$, a specific inhibitor of CDK4/6. The CXCR4 antagonist AMD3100 (100 ng/ml) blocked the effect of SDF-1 $\mu$. Data from three different experiments are reported in the graph as mean $\pm \mathrm{SE} ; * P<.05$ versus $\mathrm{K} 25$ and ${ }^{\wedge} P<.05$ versus K5. (B) gp120 IIIB (200 pM) does not inhibit the increase in Rb phosphorylation induced by potassium deprivation (top two panels), whereas increases the level of phosphoRb when neurons are maintained in high potassium (K25, bottom panel). Twenty micrograms of proteins were loaded in each lane. 

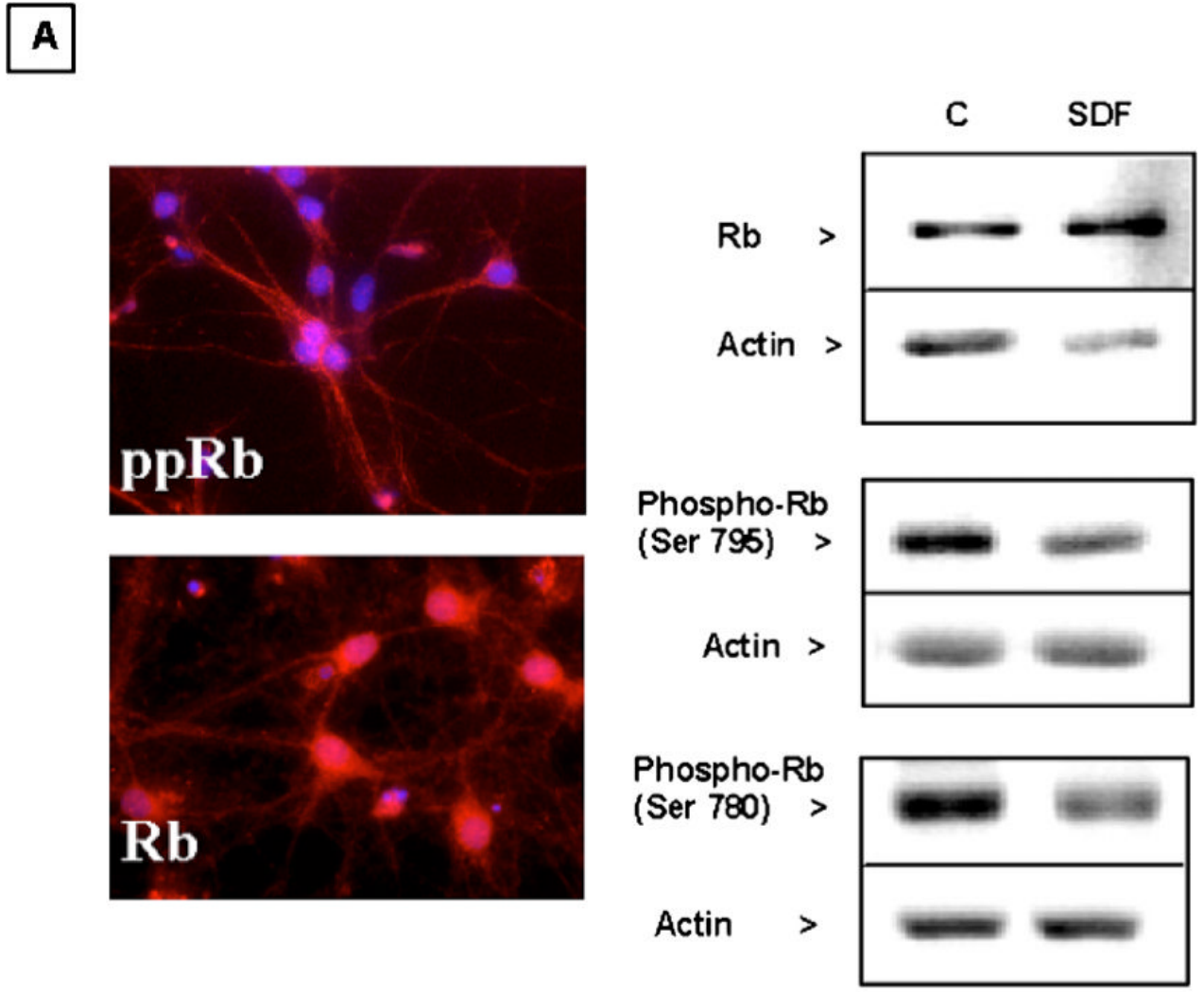

\section{B}

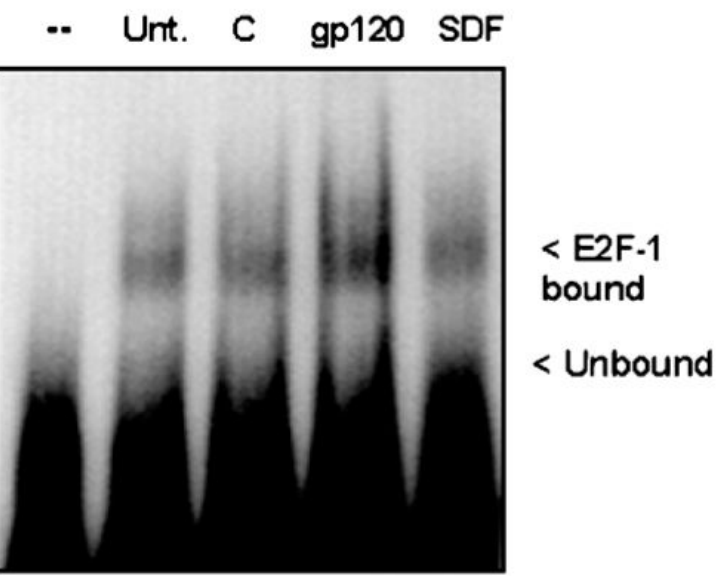

Figure 8.

Effect of SDF-1 $\mu$ and gp120IIIB on E2F-1 activity in hippocampal neurons. (A) Left: Immunostaining of phosphoRb (Ser795) and $\mathrm{Rb}$ (both in red) in control hippocampal neurons (7DIV with glia). Nuclei are counterstained with Hoechst 33342 (blue). Right: Immunoblots using total cell lysates of hippocampal neurons showed that treatment with SDF- $1 \mu(20 \mathrm{nM}, 1$ $\mathrm{h}$, without glia) increased $\mathrm{Rb}$ expression and reduces phosphoRb expression. (B) gp120 $0_{\mathrm{III}}$ increases the DNA-binding activity of E2F-1 as assessed by gel retardation assay. The first lane only contains labeled oligonucleotide. Neurons were treated with SDF-1 $\mu(20 \mathrm{nM})$ or gp120 (200 pM) in the absence of the glia feeder layer but in glia-conditioned medium (i.e., original culture medium) for $15 \mathrm{~min}$ before extraction of nuclear proteins. 